\title{
MÚLTIPLOS ENCANTAMENTOS NOS DOMÍNIOS DO ENTRE-SABER
}

Maria dos Prazeres Santos Mendes

Caro leitor, neste número três da revista Literartes, em que se consolida o intercâmbio entre especialistas e críticos em literatura e arte, sendo grande a contribuição dos ensaístas e articulistas para o estudo da literatura, outras artes e outras mídias, propomos, aqui, uma primeira leitura das palavras-chave dos artigos que contemplam os mais variados interesses e temas no processar de diferentes linguagens.

Enfocamos os artigos sobre a escritora e ilustradora mineira Angela Lago, em cuja obra primorosa 0 Cântico dos Cânticos - evidenciada em luzes e cores, na nossa capa - encontramos as palavras-chave:

- ilustração; imagem e texto, e intermedialidade no artigo de autoria de André Melo Mendes. A obra selecionada é Sua Alteza a Divinha, em que se visualiza a revitalização do espaço gráfico.

- texto-verbal e texto-imagem: chave de fruição no estudo de Liniane Haag Brum sobre a obra Psiquê, em que se opera a poeticidade na relação verbal/ visual, na recuperação do mito de Eros e Psiquê.

- público infantil; literatura eletrônica; literatura digital, no artigo de Penha Élida sobre o surgimento de uma literatura eletrônica ou digital para crianças e jovens, analisando o ciberespacinho criado por Angela Lago.

- experiência; imagem; leitor; leitura e mediação, presentes no relato e análise da vivência em sala de aula da contundente obra de Angela, Cena de Rua, pelas professoras Nannini, Medeiros e Ribeiro.

- ética e literatura; metáfora; linguagem visual, na análise de Cristiano Camilo Lopes, da obra A raça Perfeita, com parceria entre Angela Lago e Gisele Lotufo.

Para ouvirmos Angela Lago, Lourdes Guimarães retrata a interessante entrevista esclarecedora a que dá o título poético de Entre histórias, traços, cores e formas: a poética visual de Angela Lago. 
Em artigos que não se referem a Angela Lago, mas que contribuem plenamente para nossa conscientização crítica e profunda do entrecruzar de linguagens, o leitor encontrará as seguintes palavras-chave:

- alteridade, literatura infantil; fábula, no estudo de Andréa Castelaci Martins sobre a obra de Daniel Munduruku, ilustrada por Ciça Fittipaldi, As peripécias do Jabuti, em que mostra a configuração do diálogo entre culturas no diálogo verbal/visual.

- interações dialógicas; não finalização; diálogo; imaginário; criatividade poética, no artigo de Maria José Palo sobre a palavra e o imaginário em Alice Através do Espelho, de Lewis Caroll. Demonstra que no ato de narrar entre o semiósico e o linguístico, nos domínios do non sense, arquiteta-se a antilógica da prosa poética.

- infância; poesia no poema Camelôs de Manuel Bandeira, em análise de Paulo Sérgio de Proença.

- contos de fadas; série de TV; Branca de Neve; Príncipe Encantado, no estudo de Sandra Trabucco Valenzuela, em que analisa as relações a construção das personagens em Once Upon a Time, série de TV que lança olhar futuro ao clássico Branca de Neve.

Enriquecem esta edição as resenhas: "O livro e a leitura à luz do espelho" de Rodrigo da Costa Araújo sobre a obra Abra este Pequeno Livro de autoria de Jesse Klausmeier e ilustração de Susy Lee. "Tecendo Literatura: entre vozes e olhares" de Isaac Ramos, sobre o livro em homenagem a Lúcia Góes e “Esboços, fragmentos e o infinito proposto por Angela Lago", traduzindo em palavras e desenhos os poemas de Rilke, na resenha de Maria Laura Spengler.

Acompanhe também as entrevistas feitas por Euclides Lins de Oliveira Neto, com Marcelo Spalding, sobre a literatura digital como novo gênero de literatura e a de Isabella Lotufo, com Odilon Moraes, sobre o livro ilustrado tendo em vista a palavra, a imagem e o objeto.

Após esse levantamento, só nos resta desejar a você boa leitura! 